\title{
Streptococcus difficile Is a Nonhemolytic Group B, Type Ib Streptococcus
}

\author{
P. VANDAMME,${ }^{1,2 *}$ L. A. DEVRIESE, ${ }^{3}$ B. POT,${ }^{4}$ K. KERSTERS,${ }^{1}$ AND P. MELIN ${ }^{5}$ \\ Laboratory of Microbiology, Faculty of Sciences, ${ }^{1}$ Faculty of Veterinary Medicine, ${ }^{3}$ and BCCM/LMG Culture Collection, ${ }^{4}$ \\ University of Ghent, Ghent, Laboratory of Medical Microbiology, University Hospital Antwerp UIA, \\ Antwerp,$^{2}$ and Department of Medical Microbiology, University Hospital, Liège, ${ }^{5}$ Belgium
}

\begin{abstract}
Whole-cell protein electrophoretic analysis of the type strain of Streptococcus difficile (LMG 15799) revealed that this organism was indistinguishable from Streptococcus agalactiae strains. Although LMG $15799^{\mathrm{T}}(\mathrm{T}=$ type strain) was originally described as serologically untypeable, we found that this strain was a group $B$ streptococcus belonging to the capsular polysaccharide antigen type Ib group. The biochemical reactivity of $S$. difficile, which differed from the biochemical reactivity of typical $S$. agalactiae strains mainly by being less versatile, is similar to the biochemical reactivity of other group $B$, type Ib streptococci isolated from poikilothermic animals, such as fish and frogs.
\end{abstract}

Group B streptococci are isolated mainly from human and bovine sources; however, occasional infections in dogs, cats, camels, frogs, and fish have been reported $(10,23)$. The Lancefield serotyping method based on carbohydrate antigens is widely used as an aid for the identification of streptococci (18), yet, to date, only serogroup B corresponds to an individual species, Streptococcus agalactiae $(7,11)$. Other streptococcal species comprise strains belonging to multiple serogroups or untypeable strains, and members of several serogroups occur in different species $(7,11,23)$.

Recently, Eldar et al. (8) described two new streptococcal species, Streptococcus shiloi and Streptococcus difficile, which were isolated from fish with meningoencephalitis. The strains were assigned to the genus Streptococcus based on their growth characteristics. A micro-scale DNA-DNA hybridization assay in which $5 \mathrm{ng}$ of labeled reference DNA and DNAs from five other streptococcal and enterococcal species were used and a biochemical analysis were used to demonstrate that the fish isolates did not correspond to known Streptococcus species. After validation of the new species names, Eldar et al. (9) performed another study "... to elucidate the taxonomic position of S. shiloi." This study revealed that Streptococcus iniae (20) and $S$. shiloi are synonyms.

In an ongoing study on the taxonomy and epidemiology of streptococcal and enterococcal species, we found additional discrepancies between our data and the conclusions of Eldar et al. (8). Below, we demonstrate that $S$. difficile is a group B streptococcus belonging to the capsular serotype Ib group with a whole-cell protein pattern and phenotypic characteristics similar to those of other type Ib variants of $S$. agalactiae (10).

\section{MATERIALS AND METHODS}

Bacterial strains. Type and other well-characterized reference strains of all present streptococcal species were obtained from international culture collections. The other strains examined were field isolates obtained by two of us (L.A.D. and P.M.). Strains belonging to $S$. difficile, Streptococcus phocae, and reference species of the pyogenic species group $(1,23)$ and their sources are listed in Table 1 . Bacteriological purity was checked by plating and examining living and Gram-stained cells.

Whole-cell protein analysis. All strains were grown for $24 \mathrm{~h}$ on brain heart infusion agar (catalog no. 0037-17-8; Difco Laboratories, Detroit, Mich.) and

* Corresponding author. Mailing address: Laboratorium voor Microbiologie, Ledeganckstraat 35, B-9000 Ghent, Belgium. Phone: (32)9.264.5113. Fax: (32)9.264.5092. E-mail: Peter.Vandamme@rug ac.be. were incubated at 36 to $37^{\circ} \mathrm{C}$ in a microaerobic atmosphere containing approximately $5 \% \mathrm{O}_{2}, 10 \% \mathrm{CO}_{2}$, and $85 \% \mathrm{~N}_{2}$. Preparation of cellular protein extracts, polyacrylamide gel electrophoresis, densitometric analysis, normalization and interpolation of the protein profiles, and numerical analysis were performed as described by Pot et al. (22), using the GelCompar 4.0 software package (Applied Maths, Kortrijk, Belgium). The profiles were recorded and stored on a personal computer. The similarity between pairs of traces was expressed by the Pearson product moment correlation coefficient converted for convenience to a percentage.

Physiological tests. Strains were grown on Columbia agar (Lab M, Paisley, United Kingdom) supplemented with $5 \%$ sheep or cattle blood at $37^{\circ} \mathrm{C}$ in air enriched with $5 \% \mathrm{CO}_{2}$.

The Lancefield group antigen was determined with an Oxoid Streptococcal Grouping kit (Unipath, Basingstoke, United Kingdom) and a Slidex Strepto-kit latex B kit (bioMérieux, Marcy l'Etoile, France). Capsular typing was performed by a coagglutination assay (DARO group B Streptococcus serotyping test; DAKO A/S, Glostrup, Denmark).

Phenotypic characteristics as determined by the API 20 Strep and API $50 \mathrm{CH}$ (bioMérieux, La Balme-les-Grottes, Montalieu-Vercieu, France) and VITEK GPI (bioMérieux Vitek, Inc., Hazelwood, Mo.) microtest systems were analyzed at 30 and at $37^{\circ} \mathrm{C}$ according to the recommendations of the manufacturer; reagents were added after $24 \mathrm{~h}$. The medium used to inoculate the API $50 \mathrm{CH}$ gallery was a laboratory-prepared API 50 CHS medium without added cystine.

\section{RESULTS}

Polyacrylamide gel electrophoresis of whole-cell proteins. Duplicate protein extracts of several strains were prepared to check the reproducibility of the growth conditions and the preparation of the extracts. The correlation level between duplicate protein patterns was at least $94 \%$ (data not shown).

Figure 1 is a dendrogram obtained after numerical comparison and clustering of some of the species examined. All $S$. agalactiae strains and the S. difficile type strain (LMG 15977) form a single homogeneous cluster above a similarity level of $86 \%$. S. phocae and the reference taxa of the pyogenic hemolytic species group each constitute a distinct protein electrophoretic cluster. The type strains of the other streptococcal species occupied separate positions when they were included in the numerical comparison (data not shown).

Physiological tests. S. difficile LMG $15977^{\mathrm{T}}$ ( $\mathrm{T}=$ type strain) had an optimal growth temperature below $30^{\circ} \mathrm{C}$. It did not grow at $37^{\circ} \mathrm{C}$ in air; growth was observed when the organism was incubated anaerobically, and good growth (at 30 and $37^{\circ} \mathrm{C}$ ) was obtained in a microaerobic atmosphere containing about $5 \% \quad \mathrm{O}_{2}, 10 \% \quad \mathrm{CO}_{2}$, and $85 \% \quad \mathrm{~N}_{2}$. Strain LMG $15977^{\mathrm{T}}$ was nonmotile and nonhemolytic on bovine blood agar and did not grow on Slanetz-Bartley enterococcal selective medium. The CAMP test (3) was negative.

Coagglutination tests with the Oxoid Streptococcal Group- 
TABLE 1. Strains used

\begin{tabular}{|c|c|c|c|c|}
\hline Species or subspecies & LMG no. ${ }^{a}$ & Other designation $(\mathrm{s})^{b}$ & Depositor ${ }^{b, c}$ & Source (type) \\
\hline Streptococcus agalactiae & 14608 & STR 43 & & Bovine \\
\hline Streptococcus agalactiae & 14609 & STR 631 & & Bovine \\
\hline Streptococcus agalactiae & $14694^{\mathrm{T}}$ & CCUG $4208^{\mathrm{T}}$ & CCUG & Bovine milk \\
\hline Streptococcus agalactiae & 14747 & STR 765 & & Bovine mastitis \\
\hline Streptococcus agalactiae & 14836 & STR 432 & & Canine vagina \\
\hline Streptococcus agalactiae & 14838 & $1247 / 7 / \mathrm{T}$ & & Bovine mastitis \\
\hline Streptococcus agalactiae & 14839 & STR 631 & & Bovine mastitis \\
\hline Streptococcus agalactiae & 14840 & STR 623 & & Feline oral cavity \\
\hline Streptococcus agalactiae & 14847 & SHV 357 & Hommez & Porcine vagina \\
\hline Streptococcus agalactiae & 15081 & ATCC 12400,090 & ATCC & Human (type Ia) \\
\hline Streptococcus agalactiae & 15083 & ATCC 27591, A909 & ATCC & Human (type Ic) \\
\hline Streptococcus agalactiae & 15084 & CDC SS619, 18RS21 & $\mathrm{CDC}$ & Human throat (type II) \\
\hline Streptococcus agalactiae & 15085 & M732 & ATCC & Human (type III) \\
\hline Streptococcus agalactiae & 15086 & CNCTC $1 / 82$ & CNCTC & Human (type IV) \\
\hline Streptococcus agalactiae & 15087 & CNCTC $10 / 84$ & CNCTC & Human (type V) \\
\hline Streptococcus agalactiae & 15088 & ATCC $12386,090 \mathrm{R}$ & ATCC & Mutant strain of LMG 15081 (no type) \\
\hline Streptococcus agalactiae & 15089 & 419290 & & Human urinary infection (type III) \\
\hline Streptococcus agalactiae & 15090 & 419944 & & Human urinary infection (type $\mathrm{Ib}$ ) \\
\hline Streptococcus agalactiae & 15091 & 421390 & & Human urinary infection (type IV) \\
\hline Streptococcus agalactiae & 15092 & 426260 & & Human vagina (type II) \\
\hline Streptococcus agalactiae & 15093 & 454117 & & Human vagina (type V) \\
\hline Streptococcus agalactiae & 15094 & 455511 & & Human urinary infection (type III) \\
\hline Streptococcus agalactiae & 15095 & 455889 & & Human respiratory infection (type III) \\
\hline Streptococcus canis & 14833 & CCUG 27660, STR 290 & & Canine \\
\hline Streptococcus canis & $15890^{\mathrm{T}}$ & STR-T1 ${ }^{\mathrm{T}}$ & & Bovine mastitis \\
\hline Streptococcus canis & 15894 & $23668 / 2140$ & & Mink \\
\hline Streptococcus difficile & $15977^{\mathrm{T}}$ & CIP $103768^{\mathrm{T}}$ & CIP & Fish brain \\
\hline Streptococcus dysgalactiae subsp. dysgalactiae & $16023^{\mathrm{T}}$ & NCFB $2023^{\mathrm{T}}$ & $\mathrm{NCFB}$ & Bovine \\
\hline Streptococcus dysgalactiae subsp. dysgalactiae & 16024 & NCFB 2024 & NCFB & Bovine mastitis \\
\hline Streptococcus dysgalactiae subsp. dysgalactiae & 16029 & NCFB 2652 & NCFB & Canine \\
\hline Streptococcus dysgalactiae subsp. equisimilis & 15844 & CCUG 27479 & CCUG & Human \\
\hline Streptococcus dysgalactiae subsp. equisimilis & 15846 & CCUG 502 & CCUG & Human \\
\hline Streptococcus dysgalactiae subsp. equisimilis & $16026^{\mathrm{T}}$ & NCFB $1356^{\mathrm{T}}$ & NCFB & Human \\
\hline Streptococcus equi subsp. equi & 15764 & STR 674 & & Equine \\
\hline Streptococcus equi subsp. equi & $15886^{\mathrm{T}}$ & CCUG $23255^{\mathrm{T}}$ & CCUG & Equine \\
\hline Streptococcus equi subsp. zooepidemicus & $15887^{\mathrm{T}}$ & NCFB $1358^{\mathrm{T}}$ & NCFB & Bovine mastitis \\
\hline Streptococcus hyointestinalis & $14579^{\mathrm{T}}$ & $S 93^{\mathrm{T}}$ & & Porcine \\
\hline Streptococcus hyointestinalis & 14581 & S85 & & Porcine \\
\hline Streptococcus hyointestinalis & 14582 & EV $28 b$ & & Porcine \\
\hline Streptococcus iniae & $14520^{\mathrm{T}}$ & CCUG $27303^{\mathrm{T}}$ & CCUG & Dolphin \\
\hline Streptococcus iniae & 14521 & CCUG 27623 & CCUG & Dolphin \\
\hline Streptococcus parauberis & 12173 & NCFB 2018 & NCFB & Bovine mastitis \\
\hline Streptococcus parauberis & $12174^{\mathrm{T}}$ & NCFB $2020^{\mathrm{T}}$ & NCFB & Bovine mastitis \\
\hline Streptococcus phocae & $16735^{\mathrm{T}}$ & CCUG $35103^{\mathrm{T}}$ & CCUG & Seal liver \\
\hline Streptococcus phocae & 16736 & CCUG 35104 & CCUG & Seal spleen \\
\hline Streptococcus phocae & 16737 & CCUG 35105 & CCUG & Seal kidney \\
\hline Streptococcus porcinus & 14615 & STR 827 & & Human \\
\hline Streptococcus porcinus & $15980^{\mathrm{T}}$ & CCUG $27628^{\mathrm{T}}$ & CCUG & Porcine \\
\hline Streptococcus porcinus & 15981 & CCUG 27629 & CCUG & Porcine \\
\hline Streptococcus pyogenes & 14237 & CIP 56.58 & CIP & Patient with rheumatic fever, throat \\
\hline Streptococcus pyogenes & 14238 & CIP 70.3 & CIP & Patient with bronchopneumonia, pleural fluid \\
\hline Streptococcus pyogenes & $14700^{\mathrm{T}}$ & CCUG $4207^{\mathrm{T}}$ & CCUG & Patient with scarlet fever \\
\hline Streptococcus shiloi & $15978^{\mathrm{T}}$ & CIP $103769^{\mathrm{T}}$ & CIP & Fish brain \\
\hline Streptococcus uberis & 14395 & STR 192 & & Duck lung \\
\hline Streptococcus uberis & 14610 & 266/STR 203 & & Bovine \\
\hline Streptococcus uberis & 14686 & ATCC 13386 & ATCC & \\
\hline
\end{tabular}

${ }^{a}$ LMG, Laboratorium voor Microbiologie Gent Culture Collection, Universiteit Gent, Ghent, Belgium.

b ATCC, American Type Culture Collection, Rockville, Md.; CCUG, Culture Collection of the University of Göteborg, Department of Clinical Bacteriology, University of Göteborg, Göteborg, Sweden; CDC, Centers for Disease Control and Prevention, Atlanta, Ga.; CIP, Collection bactérienne de l'Institut Pasteur, Paris, France; CNCTC, Czechoslovak National Collection of Type Cultures, Institute of Hygiene and Epidemiology, Prague, Czech Republic; Hommez, J. Hommez, Regional Veterinary Investigation Centre, Torhout, Belgium; NCFB, The National Collection of Food Bacteria, Agricultural and Food Research Council, Institute of Food Research, Reading Laboratory, Reading, Berkshire, United Kingdom.

' Strains for which no depositor is indicated are our isolates. 


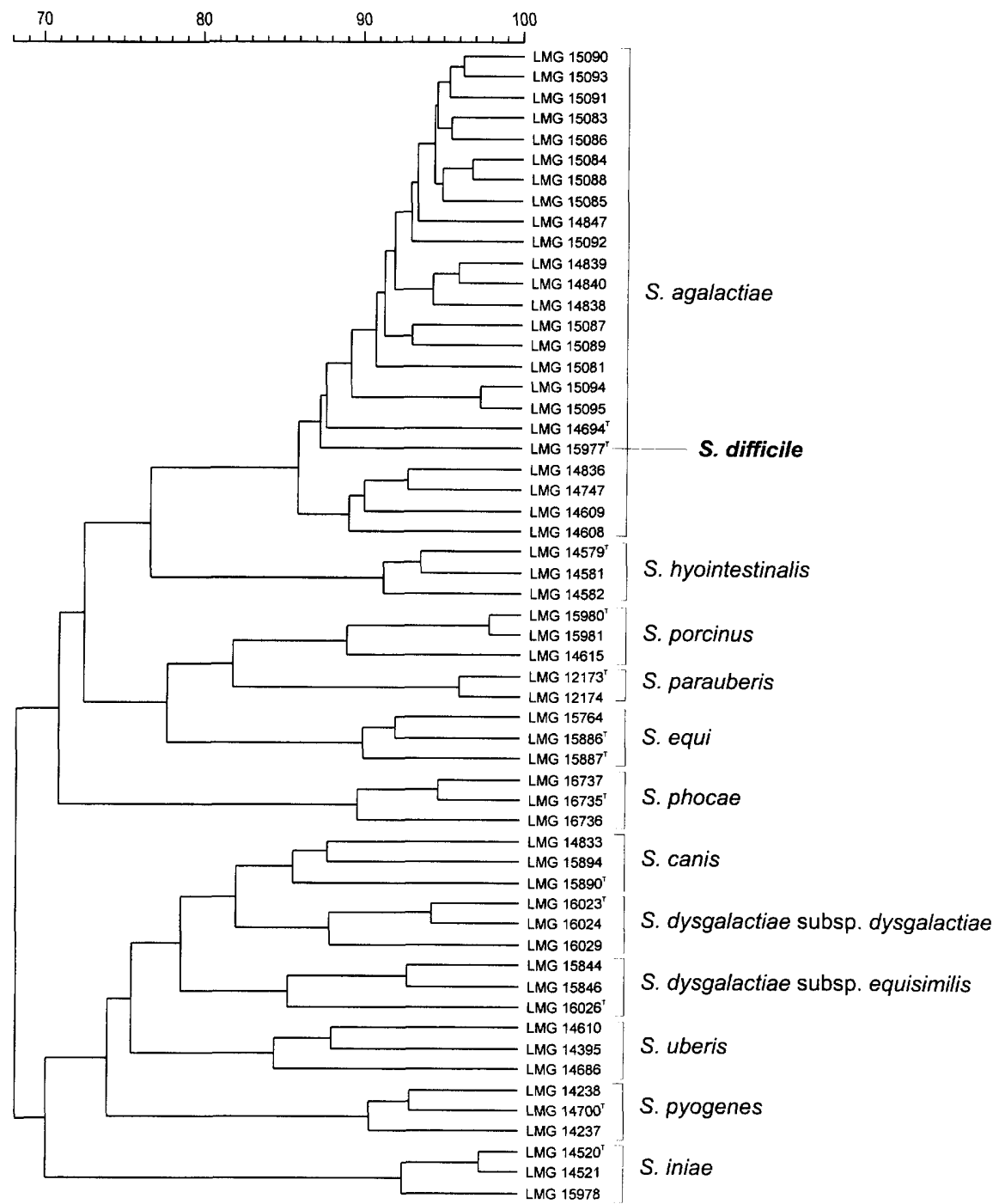

FIG. 1. Dendrogram derived from unweighed pair group average linkage of correlation coefficients (expressed for convenience as percentages) between whole-cell protein patterns of streptococci belonging to the pyogenic species group. Strain LMG 15978 is the type strain of $S$. shiloi.

ing kit and the latex agglutination test with the Slidex Streptokit both revealed that the strain possessed the Lancefield group $\mathrm{B}$ carbohydrate antigen. Capsular typing revealed the presence of the type Ib antigen.

Most results obtained with the API 20 Strep and API $50 \mathrm{CH}$ microtest systems confirmed the results of Eldar et al. (8). In contrast, hydrolysis of hippurate and beta-glucuronidase activity were detected when the gallery was incubated at $30^{\circ} \mathrm{C}$, but not when the gallery was incubated at $37^{\circ} \mathrm{C}$.

When the VITEK GPI microtest system was used, resistance to optochin and novobiocin, susceptibility to bacitracin, and acid production from D-glucose and sucrose were recorded. Acid was weakly produced from ribose. No growth occurred in the presence of $6 \% \mathrm{NaCl}, 10 \%$ bile, or $40 \%$ bile. Esculin and urea hydrolysis, arginine dihydrolase activity, reduction of tetrazolium chloride, and acid production from hemicellulase, lactose, mannitol, raffinose, salicin, sorbitol, trehalose, arabinose, pyruvate, pullulan, inulin, melibiose, melezitose, cellobiose, and xylose were all absent.

\section{DISCUSSION}

Comparative whole-organism protein electrophoresis has been used by numerous investigators to examine relationships between bacteria (for reviews see references 6,16 , and 22 ). The results of numerical analyses of one-dimensional wholeorganism protein fingerprints are often equivalent to the results obtained by DNA-DNA hybridization, as strains with very similar whole-cell protein patterns for the most part exhibit high DNA-DNA binding values. This equivalence has been widely documented in gram-negative bacteria, including the genera Alcaligenes, Arcobacter, Bordetella, Campylobacter, and Pseudomonas $(19,27,28,30)$. In gram-positive bacteria, this relationship is less well documented because of the difficulty of obtaining sufficient amounts of DNA for the hybridization experiments, yet it has been demonstrated in several genera, including the genera Clostridium, Enterococcus, Lactobacillus, Lactococcus, and Paenibacillus (4, 6, 13-15, 17, 21, 26).

The same reference strains of several Streptococcus species (including Streptococcus dysgalactiae, Streptococcus equi, $S$. 
iniae, Streptococcus parasanguis, Streptococcus parauberis, and $S$. phocae) have been included in DNA-DNA hybridization and protein electrophoretic studies (Fig. 1) (5, 9, 12, 25, 29, 33). Comparison of the results obtained with the two techniques indicates that the congruence between whole-cell protein pattern similarity and percentage of DNA-DNA binding is also present in the genus Streptococcus.

Type and other well-characterized strains of all known Streptococcus species have been examined by whole-cell protein electrophoresis in order to construct a database for identification. When the type strains of $S$. shiloi and $S$. difficile were examined, it was obvious that these strains did not represent new streptococcal species as described by Eldar et al. (8). Numerical comparison of the whole-cell protein patterns confirmed that $S$. shiloi is identical to $S$. iniae (29) (Fig. 1), as stated in a subsequent paper by Eldar et al. (9). However, we also found that $S$. difficile did not occupy a distinct position in the dendrogram. S. difficile LMG $15977^{\mathrm{T}}$ is situated among the $S$. agalactiae strains which form a homogeneous cluster (Fig. 1). Numerical analysis of whole-cell protein patterns of $S$. agalactiae strains representing types Ia, Ib, Ic, II, III, IV, and V did not reveal differences (Fig. 1), confirming the DNA-DNA hybridization data of Wanger and Dunny (31). The latter authors reported that $S$. agalactiae strains with different serotypes (serotypes Ia, Ib, Ic, II, and III) that were isolated from human and bovine sources all exhibit high DNA-DNA hybridization values. Elliot et al. (10) reported that group B type Ib streptococci isolated from humans, cows, mice, fish, and frogs all have identical protein patterns despite salient phenotypic differences. These phenotypic variants of the normal beta-hemolytic group B $S$. agalactiae strains are mainly characterized by being less versatile (i.e., by being nonhemolytic, by being CAMP negative, or by not producing acid from various sources) $(10,34)$. This was confirmed in the present study, which included different group B type Ib strains, strains from unusual sources, such as cat and dog isolates (Table 1), and a phenotypically aberrant strain from bovine mastitis (strain LMG 14838, which is negative in the CAMP assay). All of these isolates formed a single homogeneous protein electrophoretic cluster with the other $S$. agalactiae and $S$. difficile strains (Fig. 1).

Eldar et al. (8) reported that $S$. difficile was serologically untypeable. However, in two independent assays, we found that the $S$. difficile type strain clearly reacted with the group B antigen. Moreover, we found that capsular polysaccharide antigen $\mathrm{Ib}$, which is specific for $S$. agalactiae strains (23), was present. Virtually all of the phenotypic characteristics present in the API $50 \mathrm{CH}$ and API 20 Strep galleries as reported by Eldar et al. (8) were confirmed in our analyses. Acid production from ribose was weakly positive after prolonged incubation in the API galleries and after $15 \mathrm{~h}$ of incubation in the VITEK GPI system. This phenotypic profile of $S$. difficile corresponds to that of other fish-pathogenic, group $\mathrm{B}$, type $\mathrm{Ib}$ streptococci described by Wilkinson et al. (34). We found that the $S$. difficile type strain grows well at $37^{\circ} \mathrm{C}$, provided that it is incubated under microaerobic conditions. $S$. difficile $\mathrm{LMG}$ $15977^{\mathrm{T}}$ cells adhered strongly to the agar layer and were difficult to suspend, which may influence the outcome of test results. Characteristics such as beta-glucuronidase activity and hippurate hydrolysis were detected when the organisms were incubated at $30^{\circ} \mathrm{C}$ but not when they were incubated at $37^{\circ} \mathrm{C}$.

The serological classification of strain $\mathrm{LMG} 15977^{\mathrm{T}}$ as a group B type Ib streptococcus and the protein electrophoretic similarity to $S$. agalactiae strains representing different serotypes, hosts, and phenotypic variants identify this strain as an $S$. agalactiae strain. Eldar et al. (8) obtained a DNA-DNA hy- bridization value of $30.8 \%$ between strain LMG $15977^{\mathrm{T}}$ and $S$. agalactiae ATCC 27956. The latter strain is not the type strain of $S$. agalactiae, but there is no evidence to question its identity. Eldar et al. used a microscale version of the classical hydroxyapatite method (2) and $5 \mathrm{ng}$ of labeled reference DNA (8) in their hybridization assays. They considered the $17 \%$ homology between $S$. difficile LMG $15977^{\mathrm{T}}$ and $S$. shiloi LMG $15978^{\mathrm{T}}$ significant, although in the same study a DNA-DNA binding value of $37.7 \%$ was calculated between $S$. difficile LMG $15977^{\mathrm{T}}$ and an Enterococcus faecalis strain, which belongs to a distinct phylogenetic lineage (24). It is difficult to interpret these DNADNA binding values. Perhaps the conditions used for DNADNA hybridization were too stringent to reveal the level of DNA-DNA hybridization expected from the standard hydroxyapatite method and from the evidence supplied by the high similarity in whole-cell protein content, the common group B antigen, and the identification of capsular type Ib. It is not contradictory in this context that the fish isolates classified as $S$. difficile all exhibited high levels of DNA binding (8). These strains could represent a distinct marine variant of $S$. agalactiae which originated from a common ancestor and which is phenotypically adapted to its host, as suggested by Elliot et al. (10). This hypothesis is supported by the DNA-DNA hybridization data of Wanger and Dunny (31), who found that under highly stringent conditions, DNA-DNA hybridization values were higher between strains isolated from the same host, irrespective of the capsular serotype, than between strains isolated from different hosts even if they were the same capsular serotype. Obviously, a methodological comparison between the DNA binding values obtained with the standard and microscale hydroxyapatite methods is warranted before the latter technique is validly used for species delineation as described by Wayne et al. (32).

In the present study, we also included three reference strains of $S$. phocae, a beta-hemolytic species isolated from diseased seals (25). S. phocae strains are serologically heterogeneous (group antigens $\mathrm{F}$ and $\mathrm{C}$, and untypeable strains are present) and exhibited no significant DNA hybridization with other Streptococcus species. Our protein electrophoretic analysis confirmed the separate status of these organisms within the group of beta-hemolytic streptococci (Fig. 1).

\section{ACKNOWLEDGMENTS}

We thank Dirk Dewettinck for excellent technical assistance. We thank all depositors of strains listed in Table 1.

P.V. is indebted to the National Fund for Scientific Research (Belgium) for a position as a postdoctoral research fellow. K.K. is indebted to the Fund for Medical Scientific Research, Belgium, for research and personnel grants.

\section{REFERENCES}

1. Bentley, R. W., J. A. Leigh, and M. D. Collins. 1991. Intrageneric structure of Streptococcus based on comparative analysis of small-subunit rRNA sequences. Int. J. Syst. Bacteriol. 41:487-494.

2. Brenner, D. J., G. R. Fanning, A. V. Rake, and K. E. Johnson. 1969. Batch procedure for the thermal elution of DNA from hydroxyapatite. Anal. Biochem. 28:447-459.

3. Christie, R., N. E. Atkins, and E. Munch-Petersen. 1944. A note on a lytic phenomenon shown by group B streptococci. Aust. J. Exp. Biol. Med. Sci. 22:193-197.

4. Collins, M. D., B. A. Phillips, and P. Zanoni. 1989. Deoxyribonucleic acid homology studies of Lactobacillus casei, Lactobacillus paracasei sp. nov. subsp. paracasei and subsp. tolerans, and Lactobacillus rhamnosus sp. nov., comb. nov. Int. J. Syst. Bacteriol. 39:105-108.

5. Collins, M. D., J. A. E. Farrow, V. Katic, and O. Kandler. 1984. Taxonomic studies on streptococci of serological groups E, P, U and V: description of Streptococcus porcinus sp. nov. Syst. Appl. Microbiol. 5:402-413.

6. Costas, M. 1992. Classification, identification, and typing of bacteria by the analysis of their one-dimensional polyacrylamide gel electrophoretic protein patterns, p. 351-408. In A. Chambrach, M. J. Dunn, and B. J. Radola (ed.), 
Advances in electrophoresis, vol. 5. VCH Verlagsgesellschaft, Weinheim, Germany.

7. Devriese, L. A. 1991. Streptococcal ecovars associated with different animal specics: epidemiological significance of serogroups and biotypes. J. Appl Bacteriol. 71:478-483.

8. Eldar, A., Y. Bejerano, and H. Bercovier. 1994. Streptococcus shiloi and Streptococcus difficile: two new streptococcal species causing a meningoencephalitis in fish. Curr. Microbiol. 28:139-143.

9. Eldar, A., P. F. Frelier, L. Assenta, P. W. Varner, S. Lawhon, and H. Bercovier. 1995. Streptococcus shiloi, the name for an agent causing septicemic infection in fish, is a junior synonym of Streptococcus iniae. Int. J. Syst. Bacteriol. 45:840-842.

10. Elliot, J. A., R. R. Facklam, and C. B. Richter. 1990. Whole-cell protein patterns of nonhemolytic group $\mathrm{B}$, type $\mathrm{Ib}$ streptococci isolated from humans, mice, cattle, frogs, and fish. J. Clin. Microbiol. 28:628-630.

11. Ezaki, T., R. Facklam, N. Takeuchi, and E. Yabuuchi. 1986. Genetic relatedness between the type strain of Streptococcus anginosus and minute-colony-forming beta-hemolytic streptococci carrying different Lancefield group antigens. Int. J. Syst. Bacteriol. 36:345-347.

12. Farrow, J. A. E., and M. D. Collins. 1984. Taxonomic studies on streptococci of serological groups $\mathrm{C}, \mathrm{G}$ and $\mathrm{L}$ and possibly related taxa. Syst. Appl. Microbiol. 5:483-493.

13. Hertel, C., W. Ludwig, B. Pot, K. Kersters, and K.-H. Schleifer. 1993. Differentiation of lactobacilli occurring in fermented milk products by using oligonucleotide probes and electrophoretic protein profiles. Syst. Appl. Microbiol. 14:463-467.

14. Heyndrickx, M., K. Vandemeulebroecke, B. Hoste, P. Janssen, K. Kersters, P. De Vos, N. A. Logan, N. Ali, and R. C. W. Berkeley. 1996. Reclassification of Paenibacillus (formerly Bacillus) pulvifaciens (Nakamura 1984) Ash et al. 1994, a later subjective synonym of Paenibacillus (formerly Bacillus) larvae (White 1906) Ash et al. 1994, as a subspecies of $P$. lavae, with emended descriptions of $P$. larvae as $P$. larvae subsp. larvae and $P$. larvae subsp. pulvifaciens. Int. J. Syst. Bacteriol. 46:270-279.

15. Heyndrickx, M., K. Vandemeulebroecke, P. Scheldeman, B. Hoste, K. Kersters, P. De Vos, N. A. Logan, A. M. Aziz, N. Ali, and R. C. W. Berkeley. 1995 Paenibacillus (formerly Bacillus) gordonae (Pichinoty et al. 1986) Ash et al 1994 is a later subjective synonym of Paenibacillus (formerly Bacillus) validus (Nakamura 1984) Ash et al. 1994: emended description of P. validus. Int. J. Syst. Bacteriol. 45:661-669.

16. Kersters, K., B. Pot, D. Dewettinck, U. Torck, M. Vancanneyt, L. Vauterin, and P. Vandamme. 1994. Identification and typing of bacteria by protein electrophoresis, p. 51-66. In F. G. Priest, A. Ramos-Cormenzana, and B. Tyndall (ed.), Bacterial diversity and systematics. Plenum Press, New York, N.Y.

17. Kilpper-Bälz, R., G. Fischer, and K. H. Schleifer. 1982. Nucleic acid hybridization of group N and group D streptococci. Curr. Microbiol. 7:245-250.

18. Lancefield, R. C. 1933. A serological differentiation of human and other groups of hemolytic streptococci. J. Exp. Med. 59:571-591.

19. Owen, R. J., and P. J. H. Jackman. 1982. The similarities between Pseudomonas paucimobilis and allied bacteria derived from analysis of deoxyribonucleic acids and electrophoretic protein patterns. J. Gen. Microbiol. 128: 2945-2954.

20. Pier, G. B., and S. H. Madin. 1976. Streptococcus iniae sp. nov., a betahemolytic streptococcus isolated from Amazon freshwater dolphin, Inia geoffrensis. Int. J. Syst. Bacteriol. 26:545-553.

21. Pot, B, C. Hertel, W. Ludwig, P. Descheemaeker, K. Kersters, and K. H. Schleifer. 1993. Identification and classification of Lactobacillus acidophilus, L. gasseri, and L. johnsonii strains by SDS-PAGE and rRNA-targeted oligonucleotide probe hybridisations. J. Gen. Microbiol. 139:513-517.

22. Pot, B., P. Vandamme, and K. Kersters. 1994. Analysis of electrophoretic whole-organism protein fingerprints, p. 493-521. In M. Goodfellow and A. G. O'Donnell (ed.), Modern microbial methods. Chemical methods in prokaryotic systematics. J. Wiley and Sons, Ltd., Chichester, United Kingdom.

23. Rotta, J. 1986. Pyogenic hemolytic streptococci, p. 1047-1054. In P. H. A. Sneath, N. S. Mair, M. E. Sharpe, and J. G. Holt (ed.), Bergey's manual of systematic bacteriology, vol. 2. The Williams \& Wilkins Co., Baltimore, Md.

24. Schleifer, K.-H., M. Ehrmann, C. Beimfohr, E. Brockmann, W. Ludwig, and R. Amann. 1995. Application of molecular methods for the classification and identification of lactic acid bacteria. Int. Dairy J. 5:1081-1094.

25. Skaar, I., P. Gaustad, T. Tonjum, B. Holm, and H. Stenwig. 1994. Streptococcus phocae sp. nov., a species isolated from clinical specimens from seals. Int. J. Syst. Bacteriol. 44:646-650.

26. Teixeira, L. M., R. R. Facklam, A. G. Steigerwalt, N. E. Pigott, V. L. Merquior, and D. J. Brenner. 1995. Correlation between phenotypic characteristics and DNA relatedness within Enterococcus faecium strains. J. Clin. Microbiol. 33:1520-1523.

27. Vandamme, P., J. Hommez, M. Vancanneyt, M. Monsieurs, B. Hoste, B. T, Cookson, C. H. Wirsing von König, K. Kersters, and P. J. Blackall. 1995. Bordetella hinzii sp. nov., isolated from poultry and humans. Int. J. Syst. Bacteriol. 45:37-45.

28. Vandamme, P., B. Pot, E. Falsen, K. Kersters, and J. De Ley. 1990. Intraand interspecific relationships of veterinary campylobacters revealed by numerical analysis of electrophoretic protein profiles and DNA:DNA hybridizations. Syst. Appl. Microbiol. 13:295-303.

29. Vandamme, P., B. Pot, E. Falsen, K. Kersters, and L. A. Devriese. 1996 Taxonomic study of Lancefield streptococcal groups C, G, and L (Streptococcus dysgalactiae) and proposal of $S$. dysgalactiae subsp. equisimilis subsp. nov. Int. J. Syst. Bacteriol. 46:774-781.

30. Vandamme, P., M. Vancanneyt, B. Pot, L. Mels, B. Hoste, D. Dewettinck, L. Vlaes, C. Van Den Borre, R. Higgins, J. Hommez, K. Kersters, J.-P. Butzler, and H. Goossens. 1992. Polyphasic taxonomic study of the emended genus Arcobacter with Arcobacter butzleri comb. nov. and Arcobacter skirrowii sp. nov., an aerotolerant bacterium isolated from veterinary specimens. Int. J. Syst. Bacteriol. 42:344-356.

31. Wanger, A. R., and G. M. Dunny. 1985. Development of a system for genetic and molecular analysis of Streptococcus agalactiae. Res. Vet. Sci. 38:202-208.

32. Wayne, L. G., D. J. Brenner, R. R. Colwell, P. A. D. Grimont, P. Kandler, M. I. Krichevsky, L. H. Moore, W. E. C. Moore, R. G. E. Murray, E. Stackebrandt, M. P. Starr, and H. G. Trüper. 1987. Report of the Ad Hoc Committee on Reconciliation of Approaches to Bacterial Systematics. Int. J. Syst. Bacteriol. 37:463-464.

33. Whiley, R. A., and J. M. Hardie. 1989. DNA-DNA hybridization studies and phenotypic characteristics of strains within the 'Streptococcus milleri' group. J. Gen. Microbiol. 135:2623-2633.

34. Wilkinson, H. W., L. G. Thacker, and R. R. Facklam. 1973. Nonhemolytic group B streptococci of human, bovine, and ichthyic origin. Infect. Immun. 7:496-498. 